\title{
HAMA TANAMAN BELIMBING DI WILAYAH KABUPATEN BLITAR JAWA TIMUR
}

\author{
Wildan Muhlison, Hermanu Triwidodo, \& Pudjianto \\ Departemen Proteksi Tanaman, Fakultas Pertanian, Institut Pertanian Bogor \\ Jl Kamper, Kampus IPB Dramaga, Bogor 16680 \\ E-mail: siwildant@gmail.com
}

\begin{abstract}
Pests of star fruit in Blitar District, East Java. Pest attack causes the production of star fruit decreases. This study aim was to identify the pests of star fruit in Blitar District which could provide an information about pest species, damage symptoms and damage intensity. The research was conducted during August - September 2014 in Gogodeso, Karangsono and Pojok Villages at Blitar District, East Java. Observations of the pests ware done by determining the four locations of plantation on each villages randomly. Three plants sample were choosen in each plantation location diagonally. Each plant was divided into four quadrant according to wind directions. One branch in the bottom was choosen in each quadrant. Nine species were recorded as pests of starfruit in Blitar district. Pest was identified on the leaf was Pteroma plagiophleps, on the branch was Zeuzera coffeae, on the flower were Toxoptera aurantii and Maconellicoccus hirsutus, whereas those on the fruit were Toxoptera aurantii, Maconellicoccus hirsutus, Thrips javanicus, Helopeltis bradyi, Cryptophlebia leucotreta, Bactrocera dorsalis, and Bactrocera carambolae. The population density of M. hirsutus was higher in Karangsono than in other villages. The highest damage intensity was caused by Bactrocera spp., C. leucotreta and $H$. bradyi (occured in Gogodeso), whereas the highest damage intensity of T. javanicus occurred in Pojok.
\end{abstract}

Key words : damage intensity, density, pest, star fruit

\begin{abstract}
ABSTRAK
Hama tanaman belimbing di wilayah Kabupaten Blitar, Jawa Timur. Serangan hama mengakibatkan penurunan produksi buah belimbing. Tujuan penelitian ini adalah untuk mengidentifikasi serangga hama tanaman belimbing di wilayah Kabupaten Blitar yang dapat menyediakan informasi tentang jenis serangga, gejala kerusakan dan intensitas kerusakan. Penelitian dilaksanakan pada bulan Agustus - September 2014 di Desa Karangsono, Gogodeso, dan Pojok, Kabupaten Blitar, Jawa Timur. Pengamatan hama dilakukan dengan menentukan empat lokasi pertanaman pada tiap desa secara acak. Tiga tanaman sampel dipilih pada tiap lokasi pertanaman secara diagonal. Setiap tanaman dibagi menjadi empat kuadran sesuai arah mata angin. Satu cabang paling bawah dipilih pada setiap kuadran. Sembilan jenis hama belimbing ditemukan di Kabupaten Blitar. Hama yang teridentifikasi pada daun adalah Pteroma plagiophleps, pada cabang adalah Zeuzera coffeae, pada bunga yaitu Toxoptera aurantii dan Maconellicoccus hirsutus, sedangkan pada buah yaitu Toxoptera aurantii, Maconellicoccus hirsutus, Thrips javanicus, Helopeltis bradyi, Cryptophlebia leucotreta, Bactrocera dorsalis, dan Bactrocera carambolae. Kepadatan populasi $M$. hirsutus tinggi di desa Karangsono dibandingkan dengan desa lainnya. Intensitas kerusakan tertinggi yang diakibatkan oleh Bactrocera spp., C. leucotreta, dan H. bradyi terjadi di Desa Gogodeso, sedangkan intensitas kerusakan tertinggi T. javanicus terjadi di Desa Pojok.
\end{abstract}

Kata kunci : belimbing, hama, intensitas kerusakan, kepadatan populasi

\section{PENDAHULUAN}

Buah belimbing memiliki potensi ekonomi cukup tinggi dalam perdagangan buah dunia. Daerah yang merupakan sentra tanaman belimbing di Indonesia adalah Jawa Timur (Blitar), Jawa Tengah (Demak), Jawa Barat (Depok), DKI Jakarta (Jakarta Selatan) dan Sumatera Utara (Deli Serdang) (Distan, 2007). Salah satu faktor yang memengaruhi budidaya dan produksi buah belimbing adalah faktor organisme pengganggu tanaman (OPT) khususnya hama. Pengamatan hama penting dilakukan pada komoditas buah karena belum banyak laporan mengenai jenis hama, daerah sebar, dan status hama secara tepat di lapangan. DKP (2012) melaporkan hama yang menyerang tanaman belimbing manis di daerah Jakarta, diantaranya adalah lalat buah Bactrocera spp. (Diptera: Tephritidae), trips Thrips sp. (Thysanoptera: Thripidae), penggerek buah 
Crytophlebia sp. (Lepidoptera: Tortricidae), penggerek bunga Diacrotricha sp. (Lepidoptera: Pterophoridae) dan ulat kantung Pteroma sp. (Lepidoptera: Psychidae). Hama-hama ini merusak langsung buah belimbing dan bagian tanaman lain yang memengaruhi produksi buah belimbing.

Laporan mengenai jenis hama dan kerusakan pada pertanaman belimbing di Kabupaten Blitar masih belum dilaporkan, sehingga perlu dilakukan untuk memperoleh data tentang hama yang menyerang tanaman belimbing serta intensitas kerusakan akibat serangan hama. Tujuan dari penelitian ini adalah untuk mengetahui jenis hama yang menyerang tanaman belimbing dan besarnya kerusakan yang ditimbulkan pada pertanaman belimbing di wilayah Kabupaten Blitar. Hasil penelitian ini diharapkan dapat memberikan informasi mengenai jenis hama, gejala kerusakan dan intensitas serangan hama pada tanaman belimbing.

\section{METODE PENELITIAN}

Tempat dan waktu. Penelitian dilakukan di Desa Karangsono dan Gogodeso Kecamatan Kanigoro, serta Desa Pojok Kecamatan Ponggok yang merupakan sentra penghasil buah belimbing di Kabupaten Blitar. Penelitian dilaksanakan pada bulan Agustus - September 2014. Pada tiap desa ditentukan empat lokasi pertanaman secara acak dengan jumlah tanaman berkisar antara 15 - 20 tanaman yang berumur di atas lima tahun.

Pengamatan Hama Tanaman Belimbing. Setiap lokasi pertanaman ditentukan tanaman sampel sebanyak 3 tanaman yang dipilih secara diagonal dengan kriteria tanaman masih produktif. Setiap tanaman sampel dibagi dalam empat kuadran sesuai dengan arah mata angin. Pada setiap kuadran ditentukan satu cabang paling bawah sebagai unit sampel. Selanjutnya, setiap unit sampel diamati hama pada cabang, daun, bunga, dan buah, kemudian kepadatan populasi dan intensitas kerusakan.

Pengamatan hama dilakukan secara langsung, meliputi jenis hama dan gejala kerusakan yang diakibatkan pada daun, cabang, bunga, dan buah. Pengamatan pada daun ditujukan pada ulat pemakan daun. Pada cabang, pengamatan ditujukan pada penggerek cabang. Pada bunga, diamati penggerek bunga, trips, kutudaun, dan kutu putih. Pada buah, diamati kutudaun, kutu putih, trips, penggerek buah, kepik pengisap, dan lalat buah. Setiap jenis hama yang yang ditemukan pada fase pradewasa dipelihara sampai menjadi imago, kemudian dikoleksi dengan memasukkan ke dalam botol yang berisi alkohol $70 \%$ dan diidentifikasi di laboratorium.

Kepadatan Populasi Hama. Kegiatan ini dilakukan dengan cara menghitung jumlah setiap jenis hama yang ditemukan di daun, cabang, bunga, dan buah pada setiap bagian unit sampel. Hama-hama yang dihitung kepadatan populasinya diantaranya, yaitu ulat kantung, penggerek bunga, kutu putih, dan kutudaun.

Intensitas Kerusakan Serangan Hama. Kegiatan ini dilakukan dengan mengamati gejala kerusakan yang terjadi pada cabang, ranting dan buah. Pada setiap cabang dan ranting, diamati gejala kerusakan yang diakibatkan oleh penggerek cabang. Pada setiap buah, diamati gejala kerusakan yang diakibatkan oleh trips, kepik pengisap, penggerek buah, dan lalat buah. Intensitas kerusakan hama dihitung dengan menggunakan rumus:

$$
\mathrm{IK}=\left[\frac{\mathrm{a}}{(\mathrm{a}+\mathrm{b})}\right] \times 100 \%
$$

dengan:

IK = intensitas kerusakan

a = jumlah bagian tanaman yang terserang

$\mathrm{b}=$ jumlah bagian tanaman yang tidak terserang

Analisis Data. Data inventarisasi hama disajikan secara deskriptif, sedangkan data kepadatan populasi dan intesitas kerusakan hama diolah dengan menggunakan software Microsoft Excel 2010 dan dianalisis dengan ANOVA, kemudian diuji lanjut menggunakan uji Duncan taraf nyata $5 \%$.

\section{HASIL DAN PEMBAHASAN}

Jenis Hama Tanaman Belimbing. Berdasarkan hasil pengamatan ditemukan sebanyak 9 jenis hama pada tanaman belimbing. Masing-masing hama menyerang bagian tanaman yang berbeda-beda seperti daun, cabang, bunga dan buah (Tabel 1).

\section{Ulat Kantung Pteroma plagiophleps Hampson} (Lepidoptera: Psychidae). Larva $P$. plagiophleps memakan daun yang masih muda terutama pada bagian bawah daun mengakibatkan daun berlubang dan kering (Gambar 1A). Gejala kerusakan pada daun diakibatkan oleh aktivitas makan $P$. plagiophleps pada lapisan epidermis bagian bawah dan jaringan mesofil yang menyisakan jaringan epidermis bagian atas, sisa epidermis atas tersebut mengering dan menyisakan 
Tabel 1. Jenis hama pada tanaman belimbing di Kabupaten Blitar

\begin{tabular}{lcc}
\hline \multicolumn{1}{c}{ Nama ilmiah } & Famili & Bagian yang diserang \\
\hline Pteroma plagiophleps & Psychidae & Daun \\
Zeuzera coffeae & Cossidae & Cabang \\
Toxoptera aurantii & Aphididae & Bunga dan buah \\
Maconellicoccus hirsutus & Pseudococcidae & Bunga dan buah \\
Thrips javanicus & Thripidae & Buah \\
Helopeltis bradyi & Miridae & Buah \\
Cryptophlebia leucotreta & Tortricidae & Buah \\
Bactrocera carambolae & Tephritidae & Buah \\
Bactrocera dorsalis & Tephritidae & Buah \\
\hline
\end{tabular}
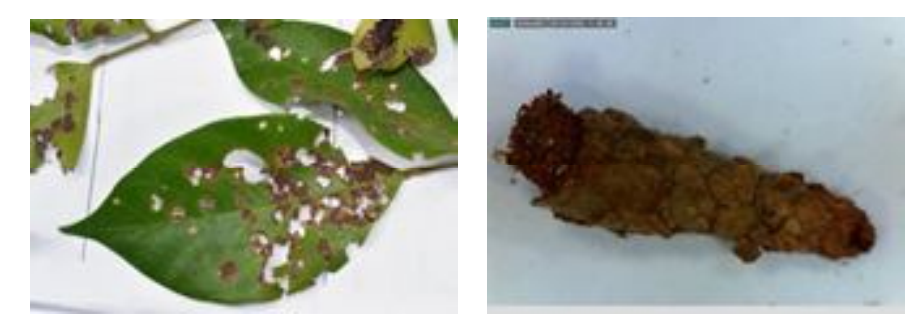

Gambar 1 Gejala serangan P. plagiophleps, (A) pada daun dan (B) larva

tulang daun (Emmanuel et al., 2012). Serangan $P$. plagiophleps pada tanaman belimbing pernah dilaporkan sebelumnya menyerang pada pertanaman belimbing di daerah DKI Jakarta (DKP, 2012). Larva P. plagiophleps termasuk hama polifag karena dapat menyerang berbagai jenis tanaman inang, seperti sengon, akasia, bakau, pinus, kelapa, kakao, jeungjing, asam jawa, flamboyan, malaka, jamblang, jati, dan anggrung (Nair, 2007; Emmanuel et al., 2012). Wilayah sebaran P. plagiophleps, meliputi Sri Lanka, India, Bangladesh dan Asia Tenggara, termasuk Indonesia (Aprilia, 2011).

Larva $P$. plagiophleps menghabiskan hidup di dalam kantung. Panjang kantung berukuran tidak lebih dari $16 \mathrm{~mm}$, berbentuk kerucut dan berwarna coklat (Gambar 1B). Kantung P. plagiophleps terbuat dari potongan-potongan daun substrat inang yang sangat kecil yang ditempelkan dengan rapi menggunakan sutera yang dihasilkan larva. Pupa berada di dalam kantung dengan posisi berubah yaitu kepala di bagian bawah kemudian kantung menjadi elips dan menggantung menggunakan benang sutera pada dahan atau daun (Emmanuel et al., 2012).

Penggerek Batang Zeuzera coffeae Nietner (Lepidoptera: Cossidae). Gejala kerusakan akibat hama Z. coffeae ditandai dengan bekas gerekan bercampur dengan kotoran di permukaan lubang gerekan (Gambar 2A). Larva menggerek ke dalam cabang, kemudian memakan bagian empulur (Gambar 2B), sehingga mengakibatkan bagian tanaman di atas lubang gerekan mengalami nekrosis, kering, merana, dan mati (Nair, 2007). Intensitas kerusakan pada tanaman belimbing di wilayah Kabupaten Blitar yang disebabkan oleh Z. coffeae berkisar antara 4,17\%. Hama ini belum pernah dilaporkan menyerang pada tanaman belimbing sebelumnya. Tanaman inang hama ini yang telah dilaporkan adalah kopi, jeruk, kakao, teh, kapuk, jambu, pohon-pohon hutan seperti jati, mahoni, cendana, dan akasia (Kalshoven, 1981; Nair, 2007). Wilayah sebaran meliputi Asia Tengah, Asia Selatan, dan Asia Tenggara, termasuk Indonesia. Larva berwarna merah kecoklatan cerah dan panjangnya kisaran 3-5 cm. Pupa berada di dalam liang gerekan. Imago memiliki sayap depan berbintik hitam dengan dasar putih transparan (CABI, 2014).

Kutudaun Toxoptera aurantii Boyer de Fonscolombe (Hemiptera: Aphididae). Hama T. aurantii hidup berkoloni dan menyerang pada bunga dan buah belimbing yang masih muda. Serangan pada bunga mengakibatkan bunga kering dan diselimuti lapisan berwarna hitam (Gambar 3A), sebagai akibat infeksi cendawan. Hal ini 

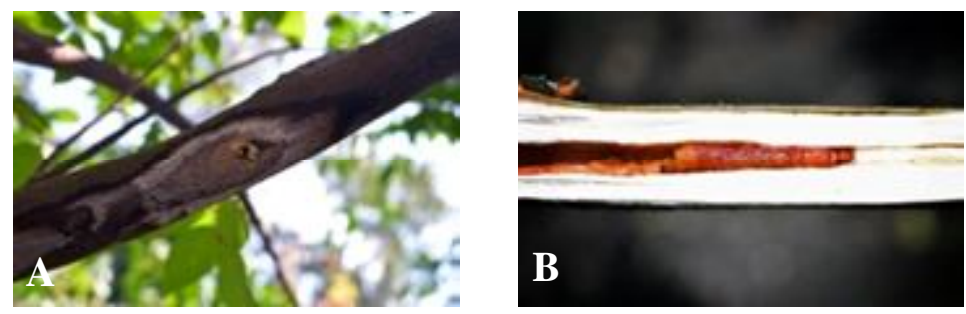

Gambar 2. Gejala serangan Z. coffeae, (A) lubang gerekan dan (B) larva menggerek cabang
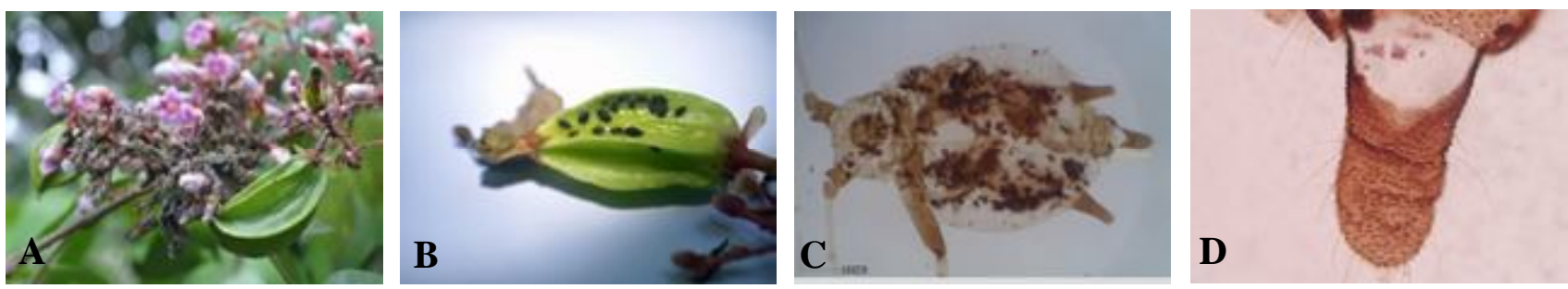

Gambar 3. Gejala serangan T. aurantii, (A) dompolan bunga, (B) buah muda, (C) panjang tubuh < 2mm, (D) kaudal dengan rambut 10-22

mengakibatkan bunga gagal berkembang menjadi buah. Serangan pada buah muda mengakibatkan buah mengalami malformasi (Gambar 3B). Gejala kerusakan terjadi sebagai akibat dari aktivitas makan yang menghisap cairan jaringan tanaman, sehingga jaringan tanaman menjadi kering (Agarwala \& Bhattacharya, 1995).

Imago T. aurantii berbentuk oval berwarna hitam, antena berwarna hitam putih berselingan, kaudal dan kornikel berwarna hitam. Ciri morfologi T. aurantii yaitu panjang tubuhnya tidak lebih dari $2 \mathrm{~mm}$ (Gambar 3C), kaudal berbentuk seperti lidah dengan rambut berjumlah 10-21 helai (Gambar 3D), dan memiliki stridulatory apparatus di bagian bawah abdomen (Carver, 1978). Serangan T. aurantii pernah dilaporkan menyerang tanaman belimbing di Bogor (Sinaga, 2014), namun belum pernah dilaporkan tingkat serangannya. Wilayah sebaran T. aurantii meliputi seluruh daerah tropis dan subtropis termasuk kepulauan Pasifik dan merupakan hama polifag dengan tanaman inangnya, antara lain jeruk, kopi, kakao, teh, mangga, sirsak, nangka, manggis, pisang, lemon, sawo, dan belimbing (Sinaga, 2014).

Kutu Putih Maconellicoccus hirsutus Green (Hemiptera: Pseudococcidae). Hama M. hirsutus menyerang pada bunga (Gambar 4A) dan pangkal buah belimbing (Gambar 4B). Serangan hama M. hirsutus pada bunga mengakibatkan bunga rontok dan gagal menjadi buah. Selanjutnya serangan pada tangkai buah mengakibatkan buah rontok sebelum waktunya sedangkan pada buah mengakibatkan buah mengalami malformasi. Kerusakan yang diakibatkan $M$. hirsutus merupakan hasil aktivitas makan yang mengeluarkan toxic saliva yang mengakibatkan jaringan tanaman rusak dan mati (Chong, 2009). Hama M. hirsutus belum pernah dilaporkan menyerang tanaman belimbing sebelumnya. Hama ini bersifat polifag yang mempunyai banyak inang, diantaranya jambu biji, sirsak, srikaya, rambutan, kembang sepatu, kakao, jeruk, beringin, jati dan tersebar di bagian Asia Selatan sampai Asia Tenggara termasuk Indonesia (Williams \& Watson, 1988; Nasution, 2012). Ciri morfologi imago M. hirsutus yaitu antena dengan 9 ruas (Gambar 4C), memiliki circulus pada bagian ventral abdomen (Gambar 4D), tungkai belakang tanpa translucent pores, dan jumlah cerarii $5-7$ pasang (Williams \& Watson, 1988).

Trips Thrips javanicus Priesner (Thysanoptera: Thrips). Hama T. javanicus menyerang bagian bunga dan buah belimbing yang masih muda, serangan ini mengakibatkan buah yang berkembang mengalami malformasi dan permukaan menjadi berwarna keperakan yang muncul dari bagian pangkal buah (Gambar 5A). Serangan tertinggi di wilayah Kabupaten Blitar terjadi pada musim kemarau dengan intensitas kerusakan berkisar antara $0,24-26,67 \%$. Serangan yang tinggi dapat mengakibatkan permukaan buah menjadi kecoklatan diikuti pecahnya permukaan buah (Gambar 5B). Gejala serangan ini seperti yang terjadi pada buah pisang, alpukat, jeruk, anggur dan strawberi (Vierbergen \& Reynaud, 2005). Wilayah sebaran T. javanicus meliputi pulau Jawa yang dilaporkan menyerang pada 

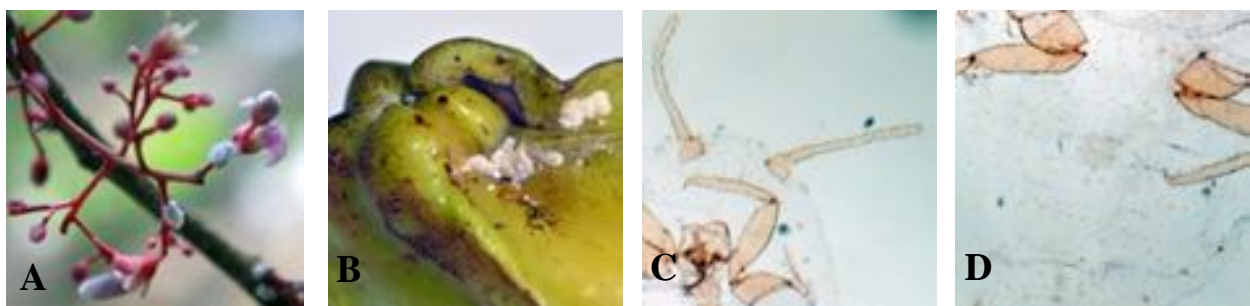

Gambar 4. Gejala serangan M. hirsutus, (A) dompolan bunga dan (B) pangkal buah (C) antena 9 ruas dan (D) circulus pada ventral abdomen
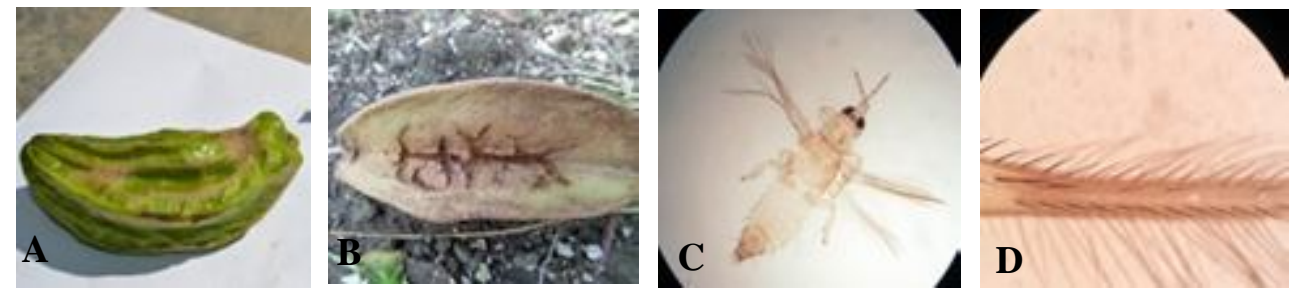

Gambar 5. Gejala serangan T. javanicus, (A) malformasi buah (B) buah burik dan pecah-pecah (C) imago T. javanicus dan (D) penampang sayap depan antara seta venasi pertama dan kedua

belimbing manis dan jeruk (Sartiami \& Mound, 2013; Subagyo, 2014), namun belum ada laporan mengenai tingkat serangannya.

Imago T. javanicus (Gambar 5C) mirip dengan Thrips parvispinus, namun yang membedakan adalah pada seta venasi sayap depan. Deretan seta pada venasi pertama sayap depan $T$. javanicus tidak lengkap, sedangkan pada venasi keduanya lengkap (Gambar 5D), antena 7 ruas, tidak terdapat microtrichia pada tergit abdomen ruas VIII, dan tidak terdapat seta diskal pada sternit abdomen (Subagyo, 2014).

Kepik Pengisap Helopeltis bradyi Waterhouse (Hemiptera: Miridae). Serangan hama $H$. bradyi mengakibatkan permukaan buah mengalami nekrotik berupa bercak cekung ke dalam yang berwarna coklat sampai kehitaman (Gambar 6A). Gejala ini disebabkan proses makan dari $H$. bradyi dengan menusukkan stilet ke dalam jaringan buah dan menghisap cairan di dalamnya yang bersamaan mengeluarkan cairan ludah, sehingga mengakibatkan kematian jaringan tanaman di sekitar tusukan (Sudarmadji, 1989). Serangan pada buah yang masih muda mengakibatkan buah kering dan rontok, sedangkan serangan pada buah yang telah matang mengakibatkan buah cacat fisik. Intensitas kerusakan pada tanaman belimbing di wilayah Kabupaten Blitar yang disebabkan oleh $H$. bradyi berkisar antara $6,84 \%$. Serangan hama ini belum pernah dilaporkan menyerang tanaman belimbing sebelumnya. Wilayah sebaran $H$. bradyi meliputi India Selatan, Indonesia, Malaysia, Sri Lanka, dan Singapura. Tanaman inangnya, antara lain kakao, teh, jeruk, kopi, jambu monyet, kina, gadung, dan akasia . Ciri morfologi H. bradyi, yaitu antena ruas pertama lebih panjang dibandingkan lebar pronotum bagian bawah (Gambar 6B) dan pangkal femur belakang melebar dengan pola berwarna pucat (Stonedahl, 1991).

Penggerek Buah Cryptophlebia leucotreta Meyrick (Lepidoptera: Tortricidae). Larva $C$. leucotreta menggerek buah belimbing, mengakibatkan gejala serangan yaitu adanya serpihan gerekan dan eksudat pada permukaan lubang gerekan (Gambar 7A). Buah yang telah digerek mengalami cacat fisik berupa pembusukan pada area disekitar lubang gerekan (Gambar 7B). Intensitas kerusakan pada tanaman belimbing di wilayah Kabupaten Blitar yang disebabkan oleh $C$. leucotreta berkisar antara 0,23-5,45\%. Hama ini menjadi hama utama pada buah belimbing dan buah lainnya, seperti alpukat, pisang, apel, kopi, kapas, anggur, mangga, lemon, jeruk, jambu, leci, dan jagung (Stotter, 2009).

Larva $C$. leucotreta instar akhir memiliki ciri khas yaitu berwarna merah muda sampai merah, memudar pada bagian sisi samping, kepala berwarna merah terang, dan pronotum berwarna coklat kekuningan (Gambar 7C) (USDA, 2010). Imago C. leucotreta (Gambar 7D) berukuran panjang 6-12 mm dengan warna coklat keabu-abuan, sayap depan memanjang dengan triangular patch berwarna hitam, sayap belakang berwarna coklat muda pucat, tibia bagian belakang dengan lempeng sisik yang termodifikasi, dan apical spur melebar dengan sisik yang bertumpuk (Venette et al., 2003). 

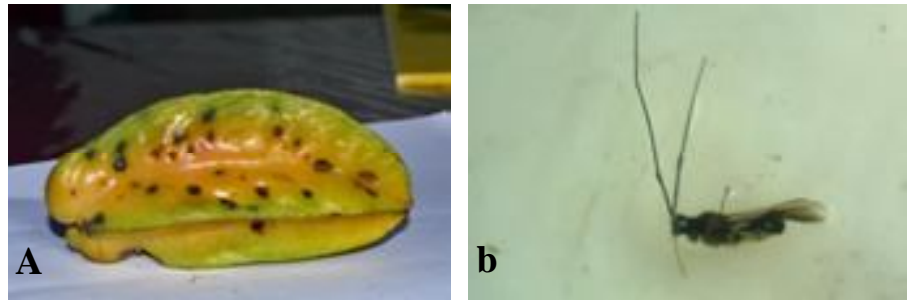

Gambar 6. Gejala serangan H. bradyi, (A) buah dan (B) imago.
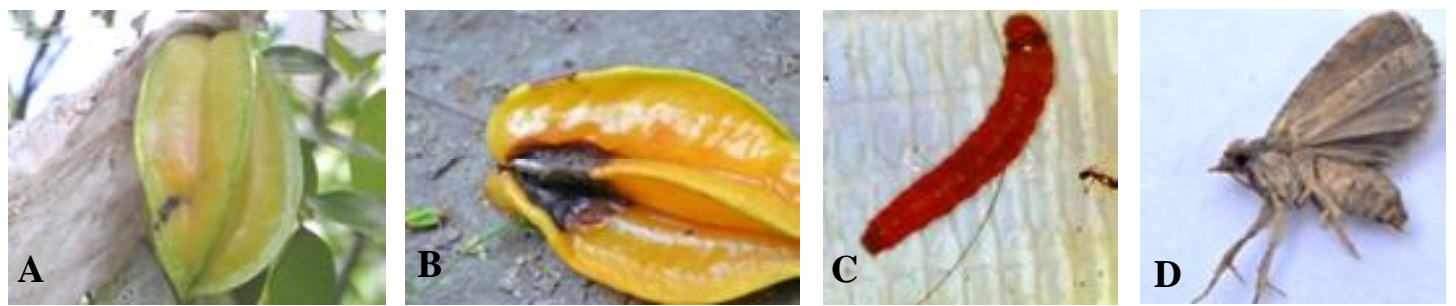

Gambar 7. Gejala serangan C. leucotreta, (A) buah belimbing dengan bekas gerekan (B) buah cacat fisik (C) larva instar akhir (D) imago

Lalat Buah Bactrocera spp. (Diptera: Tephritidae). Serangan lalat buah mengakibatkan buah menjadi busuk dan rontok. Bekas tusukan ovipositor mengakibatkan bintik-bintik hitam diikuti dengan nekrotik di sekitarnya (Gambar 8A). Larva mempunyai tiga instar dalam waktu berkisar antara 6 - 10 hari di dalam jaringan buah (Putra \& Suputa, 2013). Larva instar akhir keluar dari jaringan buah dan melentingkan tubuhnya ke tanah untuk berpupa. Buah yong rontok dapat memberikan peluang bagi imago lalat buah untuk meletakkan telur. Serangan lalat buah pada buah belimbing di wilayah Lampung Barat mengakibatkan kehilangan hasil berkisar antara 60 $100 \%$ (Nismah \& Susilo, 2008), sedangkan intensitas kerusakan buah belimbing di wilayah Kabupaten Blitar berkisar antara 2,58-19,75\%. Rendahnya intensitas kerusakan ini dikarenakan pertanaman belimbing di wilayah Kabupaten Blitar diberikan perlakuan pembungkusan buah, sehingga peluang buah yang terserang semakin kecil.

Lalat buah yang ditemukan menyerang buah belimbing berdasarkan hasil inkubasi buah yang terserang adalah Bactrocera carambolae Drew \& Hancock dan Bactrocera dorsalis Hendel. Ciri utama morfologi $B$. carambolae yaitu costal band sayap tumpang tindih terhadap R2+3, abdomen memiliki pola $\mathrm{T}$ dengan medial longitudinal dark band melebar, dan sudut anterolateral pada terga ke IV berbentuk persegi (Gambar 8B). Ciri utama morfologi $B$. dorsalis yaitu costal band sayap terletak sejajar atau melewati $\mathrm{R} 2+3$, abdomen memiliki pola $\mathrm{T}$ dengan medial longitudinal dark band yang menyempit, dan sudut anterolateral pada terga IV yang berbentuk segitiga atau tidak ada (Gambar 8C). Kedua jenis lalat buah ini merupakan hama polifag dan memiliki sebaran inang yang luas, antara lain belimbing, nangka, mangga, pepaya, jeruk siam, jambu air, jambu biji, jambu bol, sirsak, srikaya, alpukat, cabai besar, cabai rawit, sukun, cempedak, rambutan dan belimbing wuluh (Suputa et al., 2010).

\section{Kepadatan Populasi dan Intensitas Kerusakan} Serangan Hama. Kepadatan populasi M.hirsutus di desa Karangsono nyata lebih tinggi dibandingkan di Desa Gogodeso dan Pojok (Tabel 2). Tingginya kepadatan populasi ini terkait dengan vegetasi selain tanaman belimbing di Desa Karangsono yang didominasi oleh tanaman jambu. Nasution (2012) melaporkan tanaman jambu adalah salah satu inang utama dari $M$. hirsutus. Terdapat dugaan $M$. hirsutus pindah ke pertanaman belimbing ketika sumber daya di tanaman jambu tidak tersedia. Kepadatan populasi hama $T$. aurantii dan $P$. plagiophleps tidak berbeda nyata di tiga desa. Hal ini terkait dengan tanaman belimbing manis yang merupakan salah satu inang dari $T$. aurantii dan $P$. plagiophleps (DKP, 2012; Sinaga, 2014), sehingga populasinya cenderung merata di tiga desa.

Intensitas kerusakan yang disebabkan oleh Bactrocera spp., C. leucotreta dan H. bradyi di Desa Gogodeso nyata lebih tinggi dibandingkan Desa Karangsono dan Pojok (Tabel 3). Tingginya intensitas kerusakan Bactrocera spp., C. leucotreta dan $H$. bradyi di Desa Gogodeso disebabkan tidak diterapkannya sanitasi buah. Penerapan sanitasi buah meliputi pengumpulan buah yang terserang lalat buah, baik yang telah jatuh di tanah maupun yang masih di pohon dan berupa pemipiran buah yang tidak masuk kriteria pembungkusan buah. Penerapan sanitasi buah 


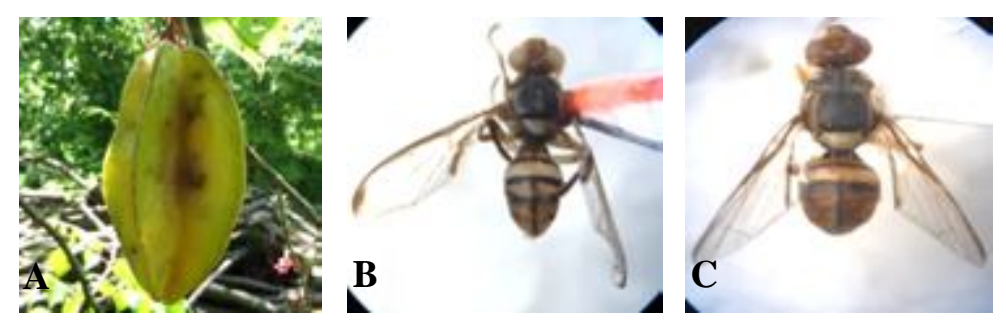

Gambar 8. Gejala serangan dan jenis lalat buah, (A) bintik hitam bekas oviposisi (B) B. carambolae (C) B. dorsalis

Tabel 2. Kepadatan populasi hama belimbing (ekor per empat cabang utama) di tiga desa

\begin{tabular}{|c|c|c|c|}
\hline \multirow[b]{2}{*}{ Hama } & \multicolumn{3}{|c|}{ Desa } \\
\hline & $\begin{array}{c}\text { Karangsono } \\
(\overline{\mathrm{x}} \pm \mathrm{SE})\end{array}$ & $\begin{array}{c}\text { Gogodeso } \\
(\overline{\mathrm{x}} \pm \mathrm{SE})\end{array}$ & $\begin{array}{c}\text { Pojok } \\
(\overline{\mathrm{x}} \pm \mathrm{SE})\end{array}$ \\
\hline M. hirsutus & $22,33 \pm 6,02 \mathrm{a}$ & $5,50 \pm 3,65 b$ & $8,75 \pm 2,65 b$ \\
\hline T. aurantii & $17,00 \pm 10,01 \mathrm{a}$ & $38,00 \pm 16,50 \mathrm{a}$ & $11,33 \pm 6,98$ \\
\hline P. plagiophleps & $1,42 \pm 0,89 \mathrm{a}$ & $0,17 \pm 0,11 \mathrm{a}$ & $2,33 \pm 1,37 \mathrm{a}$ \\
\hline
\end{tabular}

Angka pada baris yang sama yang diikuti dengan huruf yang sama tidak berbeda nyata berdasarkan uji Duncan pada taraf nyata $5 \%$; $x$. rata-rata; $\mathrm{SE}=$ standar error.

\begin{tabular}{lccr}
\hline \multirow{2}{*}{ Hama } & \multicolumn{3}{c}{ Desa } \\
\cline { 2 - 4 } & Karangsono $(\%)$ & Gododeso $(\%)$ & Pojok $(\%)$ \\
\cline { 2 - 4 } & $\left(\mathrm{x}^{-} \pm \mathrm{SE}\right)$ & $\left(\mathrm{x}^{-} \pm \mathrm{SE}\right)$ & $\left(\mathrm{x}^{-} \pm \mathrm{SE}\right)$ \\
\hline Bactrocera $\mathrm{spp}$. & $6,56 \pm 1,93 \mathrm{~b}$ & $19,75 \pm 4,81 \mathrm{a}$ & $2,58 \pm 1,29 \mathrm{~b}$ \\
C. leucotreta & $0,23 \pm 0,21 \mathrm{~b}$ & $5,45 \pm 1,54 \mathrm{a}$ & $0,69 \pm 0,38 \mathrm{~b}$ \\
T. javanicus & $1,32 \pm 1,32 \mathrm{~b}$ & $0,24 \pm 0,24 \mathrm{~b}$ & $26,67 \pm 9,13 \mathrm{a}$ \\
H. bradyi & $0,00 \pm 0,00 \mathrm{a}$ & $6,84 \pm 3,41 \mathrm{~b}$ & $0,00 \pm 0,00 \mathrm{a}$ \\
Z. coffeae & $0,00 \pm 0,00 \mathrm{a}$ & $4,17 \pm 4,17 \mathrm{a}$ & $0,00 \pm 0,00 \mathrm{a}$ \\
\hline
\end{tabular}

Angka pada baris yang sama yang diikuti dengan huruf yang sama tidak berbeda nyata berdasarkan uji Duncan pada taraf nyata $5 \% ; \mathrm{x}=$ rata-rata; $\mathrm{SE}=$ standar error

dapat memutus generasi lalat buah selanjutnya dan memperkecil peluang oviposisi telur. Hasyim et al. (2008) melaporkan bahwa pada lokasi pertanaman yang menerapkan sanitasi buah dapat menurunkan intensitas serangan lalat buah sebanyak $20 \%$ dibandingkan dengan lokasi pertanaman yang tidak menerapkan sanitasi buah. Penerapan sanitasi buah yang tidak dilakukan di Desa Gogodeso berpengaruh juga terhadap tingginya intensitas kerusakan yang disebabkan oleh $C$. leucotreta.

Intensitas kerusakan yang disebabkan $T$. javanicus di Desa Pojok nyata lebih tinggi dibandingkan dengan Desa Gogodeso dan Karangsono (Tabel 3). Tingginya serangan di Desa Pojok karena didominasi tanaman belimbing berumur sekitar $6-10$ tahun, sedangkan di dua desa lain berumur sekitar $11-15$ tahun. Umur tanaman 6-10 tahun merupakan umur pertengahan pada tanaman belimbing yaitu umur produktif untuk menghasilkan bunga dan buah. Menurut Sudrajat et al. (2011), tanaman pada umur pertengahan cenderung memiliki tajuk yang masih terbuka, sehingga memperbesar peluang masuknya cahaya matahari dan fotosintesis yang terjadi dapat menghasilkan kandungan karbohidrat yang tinggi pada tanaman, hal ini akan merangsang pertumbuhan generatif yang ditandai dengan 
munculnya bunga dan buah. Bunga dan buah yang masih muda merupakan inang dari T. javanicus. Semakin banyak sumber daya inang, maka semakin tinggi pula intensitas kerusakan yang ditimbulkan.

Intensitas kerusakan serangan $H$. bradyi dan $Z$. coffeae hanya ditemukan di Desa Gogodeso. Hal ini karena vegetasi sekitar pertanaman belimbing di Desa Gogodeso didominasi oleh tanaman kakao. Tanaman kakao merupakan salah satu inang utama dari $H$. bradyi, sebagaimana laporan Stonedahl (1991) bahwa tanaman kakao adalah tanaman inang utama dari $H$. bradyi dan sering mengakibatkan kerusakan tinggi. Selain sebagai inang utama dari $H$. bradyi, tanaman kakao juga merupakan inang utama dari Z. coffeae (Deptan, 2002). Pertanaman kakao di Desa Gogodeso sudah tidak terawat, sehingga ada dugaan kedua hama ini pindah ke pertanaman belimbing akibat sumber daya yang tidak terpenuhi lagi.

\section{SIMPULAN}

Hama yang ditemukan menyerang tanaman belimbing di wilayah Kabupaten Blitar sebanyak 9 spesies. Hama yang menyerang daun adalah $P$. plagiophleps, Hama yang menyerang cabang adalah $Z$. coffeae, Hama yang menyerang bunga yaitu $T$. aurantii dan $M$. hirsutus. Hama yang menyerang buah yaitu $T$. aurantii, M. hirsutus, $H$. bradyi, $C$. leucotreta, B. carambolae, dan B. dorsalis. Kepadatan populasi $M$. hirsutus nyata lebih tinggi di desa Karangsono dibandingkan dengan desa lainnya. Intensitas kerusakan tertinggi yang diakibatkan oleh Bactrocera spp., C. leucotreta, dan H. bradyi terjadi di Desa Gogodeso, sedangkan intensitas kerusakan tertinggi $T$. javanicus terjadi di Desa Pojok.

\section{SANWACANA}

Penulis mengucapkan terimakasih kepada Direktorat Pendidikan Tinggi atas Beasiswa Pendidikan Pascasarjana Dalam Negeri (BPPDN) yang termasuk di dalamnya adalah dana penelitian yang diberikan.

\section{DAFTAR PUSTAKA}

Agarwala BK \& Bhattacharya S. 1995. Seasonal abundance of black citrus aphid Toxoptera aurantii in North-East India: role of temperature. Proc. Indian Natl. Sci. Acad. (B Biol. Sci.). 61(5): 377-382.
Aprilia NT. 2011. Studi pustaka hama sengon (Paraserianthes falcataria (L.) Nielsen) [Skripsi]. Institut Pertanian Bogor, Bogor.

[CABI] Centre for Agriculture and Bioscience International. 2014. Datasheet Stem Borer. CABI, Wallingford.

Carver M. 1978. The black citrus aphids Toxoptera citricidus (Kirkaldy) and T. aurantii (Boyer de Fonscolombe) (Homoptera: Aphididae). J. Aust. Entomol. 17(3): 263-270.

Chong JH. 2009. First report of the pink hibiscus mealybug, Maconellicoccus hirsutus (Green) (Hemiptera: Pseudococcidae), in South Carolina. J. Agr. Urban Entomol. 26(2):87-94.

[Deptan] Departemen Pertanian. 2002. Musuh Alami, Hama dan Penyakit Tanaman Kakao Ed ke2. Deptan, Jakarta.

[Distan] Dinas Pertanian Kota Depok. 2007. Standar Operasional Prosedur Belimbing Dewa Kota Depok. Distan, Depok.

[DKP] Dinas Kelautan dan Pertanian. 2012. Pest List Tanaman Belimbing di DKI Jakarta. DKP. Jakarta.

Emmanuel N, Sujatha A, \& Gautam B. 2010. Occurance of bag worms Pteroma plagiophleps Hamps and Clania sp. on cocoa corp. Insect Environ. 16(2): 60-61.

Hasyim A, Muryati M, \& DeKogel WJ. 2008. Population fluctuation of adult males of the fruit fly, Bactrocera tau Walker (Diptera: Tephritidae) in passion fruit orchards in relation to abiotic factors and sanitation. Indones. J. Agric. Sci. 9(1): 29-33.

Kalshoven LGE. 1981. The Pests of Crops in Indonesia. Ichtiar Baru - Van Hoeve, Jakarta.

Nair KSS. 2007. Tropical Forest Insect Pest: Ecology, Impact and Management. Cambridge, New York (US).

Nasution BA. 2012. Keanekaragaman spesies kutu putih (Hemiptera: Pseudococcidae) pada tanaman buah-buahan di Bogor [skripsi]. Institut Pertanian Bogor, Bogor.

Nismah \& Susilo FX. 2008. Keanekaragaman dan kelimpahan lalat buah (Diptera: Tephritidae) pada beberapa sistem penggunaan lahan di Bukit Rigis, Sumberjaya, Lampung Barat. J. HPT Tropika 8(2): 82-89. 
Putra NS \& Suputa. 2013. Lalat Buah Hama: Bioekologi dan Strategi Tepat Mengelola Populasinya. Smartania publishing, Yogyakarta.

Sartiami D \& Mound LA. 2013. Identification of the terebrantian thrips (Insecta, Thysanoptera) associated with cultivated plants in Java, Indonesia. ZooKeys. 306: 1-21.

Sinaga JCH. 2014. Identifikasi kutu daun (Hemiptera: Aphididae) pada tanaman buah di Bogor [skripsi]. Institut Pertanian Bogor, Bogor.

Stonedahl GM. 1991. The oriental species of Helopeltis (Heteroptera: Miridae): a review of economic literature and guide to identification. Bull. Entomol. Res. 81(4): 465-490.

Stotter RL. 2009. Spatial and Temporal Distribution of False Codling Moth Across Landscapes in the Citrusdal Area (Western Cape province, South Africa). Stellenbosch University Press, Stellenbosch.

Subagyo VNO. 2014. Identifikasi Thrips (Insecta: Thysanoptera) yang berasosiasi dengan tanaman hortikultura di Bogor, Cianjur, dan Lembang [Tesis]. Institut Pertanian Bogor, Bogor.

Sudarmadji D. 1989. Hubungan timbal balik antara Helopeltis antonii Sign. (Hemiptera: Miridae) dan buah kakao [Tesis]. Institut Pertanian Bogor, Bogor.
Sudrajat DJ, Nurhasybi, \& Zanzibar M. 2011. Hubungan umur pohon dengan produksi dan mutu benih Acacia mangium Willd., Gmelina arborea Linn., dan Eucalyptus deglupta Blume. JPHT. 8(5): 267-277.

Suputa, Trisyono YA, Martono E, \& Siwi SS. 2010. Pembaruan informasi kisaran inang spesies lalat buah di Indonesia. JPTI. 16(2): 62-75.

USDA. 2010. New Pest Response Guidlines False Codling Moth Thaumatotibia leucotreta. USDA, Washington.

Venette RC, Davis EE, DaCosta M, Heisler H, \& Larson M. 2003. Mini risk assesment False codling moth, Thaumatotibia (Cryptophlebia) leucotreta (Meyrick) [Lepidoptera: Tortricidae]. CAPS, Washington (US): Washington.

Vierbergen G \& Collins O. 2005. Scirtothrips aurantii, Scirtothrips citri, Scirtothrips dorsalis. EPPO Bull. 35: 353-356.

Williams DJ \& Watson GW. 1988. The Scale Insects of the Tropical South Pacific Region. Part 2: The Mealybugs (Pseudococcidae). CABI, Wallingford. 